\title{
ADENOSINE DEAMINASE ACTIVITY IN THE SERUM OF TYPE 2 DIABETIC PATIENTS
}

\author{
Naciye Kurtul', Sadrettin Pence ${ }^{2}$, Ersin Akarsu ${ }^{3}$, Hasan Kocoglu, ${ }^{4}$, Yemliha Aksoy, Hülya Aksoy ${ }^{6}$ \\ University of Sütcü Imam, Faculty of Science, Kahramanmaraş, Turkey: Department of Chemistry'; University of \\ Gaziantep, Faculty of Medicine, Gaziantep, Turkey: Department of Physiology ${ }^{2}$, Department of Endocrinology and \\ Metabolism $^{3}$, Department of Anesthesiology and Reanimation ${ }^{4}$; State Hospital of Gaziantep, Gaziantep, Turkey: \\ Department of Emergency and First Aid ${ }^{5}$; University of Atatürk, Faculty of Medicine, Erzurum, Turkey: Department of \\ Biochemistry $^{6}$
}

Summary: Adenosine deaminase (ADA) is suggested to be an important enzyme for modulating the bioactivity of insulin, but its clinical significance in diabetes mellitus (DM) is not yet characterized. We measured the serum level of ADA in healthy controls $(C, n=29)$ and type 2 diabetic patients $(n=42)$. The mean serum level of ADA in $C$, and type 2 diabetic patients were $29.81 \pm 9.15$ and. $20.73 \pm 8.42 \mathrm{U} / \mathrm{L}$, respectively ( $\mathrm{P}<0.006$ vs. $\mathrm{C}$ ). ADA levels of patients were significantly correlated with HbAlc $(\mathrm{r}=0.45, \mathrm{p}<0.01)$. Our findings suggest that ADA may play a role in insulin effect and glycamic control. On the other hand, increased activity of ADA in type $2 \mathrm{DM}$ might be a marker for insulin indication. However, further studies are required for the pathogenic role of elevated ADA activity in type 2 DM.

Key words: Adenosine deaminase; Type 2 Diabetes mellitus

\section{Introduction}

Diabetes Mellitus (DM), a common disorder of glucose homeostasis affecting $5 \%$ of the general population, is characterized by an absolute or relative deficiency of insulin and insulin resistance. Insulin resistance is a primary risk factor in type $2 \mathrm{DM}(8,14)$.

Adenosine, a degradation product of adenine nucleotides, has been proved to play an important role in modulation of insulin action on glucose metabolism in different tissues (30).

Adenosine deaminase (ADA) is a purine metabolic enzyme that specifically catalyzes the deamination of adenosine to inosine contributing to the regulation of intracellular and extracellular concentrations of adenosine $(3,15)$, and probably modulates energy metabolism (3).

Insulin acts on peripheral tissues to stimulate glucose transport, glycogen storage, and glycolysis and as inhibitor of net hepatic glucose output (NHGO) (11,17,24,25,27). Adenosine acts directly to stimulate insulin activity via several processes such as glucose transport, lipid synthesis, pyruvate dehydrogenase activitiy, leucine oxidation and cyclic nucleotid phosphodiesterase activity $(15,16,24,29$, 30,32). There are also some data indicating altered

ADA activity of the various tissue of diabetic $(16,34)$ and streptozotocin treated rats $(16,26)$. In this study we have investigated the alteration of serum ADA activity in type 2 diabetic patients.

\section{Materials and Methods}

We studied the ADA activity in type 2 diabetic patients $(n=42,19$ men and 23 women; $39-74$ years, mean $56.6 \pm 8.8$ years) who were hospitalized for metabolic control of DM. All patients were using oral hypoglycemic agent. None of the chronic complications of diabetes were detected in the patients. Blood pressure was normal in all of them. Twenty nine healthy donors ( 15 men and 14 women ; 47-68 years, mean $56.1 \pm 6.8$ years) served as control subjects. Body mass index (BMI) was between 23 and $27 \mathrm{~kg} / \mathrm{m}^{2}$. Diabetic patients were divided into two groups according to the hemoglobin A1c (HbAlc) level, as patients whose HbA1c levels were less than $7 \%$ and higher $7 \%$. Serum ADA activity was measured according using a spectrophotometer to the method of Giusti et al. (13). ADA activity is described as U/L. One enzyme unit was the amount of enzyme necessary to convert $1 \mu \mathrm{M}$ of adenosine and ammonia per min at $37^{\circ} \mathrm{C}$.

Results were analyzed by using SAS pocket programme. All data were presented as means \pm SD. Student's t-test was used to evaluate the results statistically. Differences between mean were considered significant when $p<0.05$. In addition, correlation analaysis was performed. 


\section{Results}

Results are given in Table 1. As seen in the Table, serum levels of ADA were significantly $(p<0.01)$ elevated in type 2 diabetic patients compared to those of healthy controls. ADA leves were significantly correlated with both HbA1c $(r=0.45, p<0.01)$ and uric acid $(r=0.31, p<0.05)$. On the other hand, both serum triglyseride and uric acid were significantly higher than that of $C \quad(p<0.05$ and $\mathrm{p}<0.01$, respectively, Table 1).

Tab. 1: Comparison of parameters of patients with type 2 $\mathrm{DM}$ and controls (mean $\pm \mathrm{SD})$.

\begin{tabular}{|l|l|l|}
\hline & $\begin{array}{l}\text { Controls (C) } \\
(\mathrm{n}=29)\end{array}$ & $\begin{array}{l}\text { Type 2 DM } \\
(\mathrm{n}=42)\end{array}$ \\
\hline Diabetes duration (years) & - & $5.4 \pm 1,2$ \\
\hline Fasting glucose (mg/dL) & $91.7 \pm 7.04 * *$ & $235.5 \pm 106.7$ \\
\hline Age (years) & $56.1 \pm 6.8$ & $56.8 \pm 8.9$ \\
\hline Triglyceride (TG; mg/dL) & $173.9 \pm 38.8^{*}$ & $227.4 \pm 138.9$ \\
\hline $\begin{array}{l}\text { Total Cholesterol } \\
(\mathrm{TC} ; \mathrm{mg} / \mathrm{dL})\end{array}$ & $182.1 \pm 15.1$ & $193.95 \pm 60.7$ \\
\hline Creatinin (mg/dL) & $0.7 \pm 0.2$ & $0.8 \pm 0.1$ \\
\hline Uric acid & $3.7 \pm 1.2 * *$ & $5.4 \pm 2.5$ \\
\hline HbA $1 \mathrm{c}(\%)$ & $5.3 \pm 0.9 * *$ & $10.3 \pm 2.4$ \\
\hline ADA (U/L) & $13.04 \pm 3.3$ & $\begin{array}{l}22.2 \pm 4.3 * * \\
\mathrm{a}: 17.3 \pm 2.04 * \\
(\mathrm{n}=16) \\
\end{array}$ \\
& & $\begin{array}{l}\mathrm{b}: 23.1 \pm 4.03 * * \\
(\mathrm{n}=26)\end{array}$ \\
\hline
\end{tabular}

$* \mathrm{P}<0.05, * * \mathrm{P}<0.001$

a: Well controlled diabetic patients $\left(\mathrm{HbA}_{1 \mathrm{c}}<7\right)$,

b: Poorly controlled diabetic patients $\left(\mathrm{HbA}_{1 \mathrm{c}}(\geq 7)\right.$.

\section{Discussion}

DM is a heterogeneous disease characterized by an absolute or relative deficiency of insulin and insulin resistance. Clinical manifestations include hyperglycemia, glycousuria, altered protein, fat, and carbohydrate metabolism $(8,14)$.

Insulin acts on peripheral tissues to stimulate glucose transport, glycogen storage, and glycolysis $(11,17,25,27)$ and stimulates hepatic glucose oxidation and decreases gluconeogenesis. Previous works have demonstrated that ubiquitous purine nucleoside adenosine differentially modulates the action of insulin in various tissues, i.e., potentiation in adipose tissue $(18,31,33)$ and myocardium (23) and inhibition in skeletal muscle $(4,5,9,28)$. Some adenosinereseptor- mediated activity is required for insulin to stimulate myocardial glucose uptake (22). Adenosine modulates hepatic responsiveness to insulin and may induce local insulin resistance. Also, the modulatory effects of adenosine on hepatic responsiveness to insulin are similar to that in skeletal muscle, i.e., induce insulin resistance (24). In another study, it is supported that adenosine exerts a post-receptor insulin modulatory action in skeletal muscle (6).

Adenosine has been shown to increase gluconeogenesis (22) and glycogenolysis $(9,10,28)$. In vivo $(5,9,28)$ and in vitro studies have shown that adenosine can stimulate glucose formation $(10,22)$. In contrast, adenosine has been shown to decrease $(12,21)$ or have no effect on (5) gluconeogenesis, and have no effect on glycogenolysis (2). The reasons for these disparities are not clear, although some studies have suggested that methodological differences might account for a part of the disparities $(7,12)$.

Adenosine production and utilization in mammalian tissues are primarily dependent on the activity of producing enzyme 5'-nucleotidase (EC 3.1.3.5) and two utilizing enzymes ADA (EC 3.5.4.4) and adenosine kinase (EC 2.7.1.20) (16). There are some data indicating that insulin may effect metabolism of adenosine by changing activities of 5'-nucleotidase and ADA (30). On the other hand, 5'-nucleotidase and ADA activities were not changed in isolated glomeruli of streptozotocin diabetic rats whereas adenosine kinase activity was decreased by approximately $70 \%$ in diabetic rats (1). It is suggested that insulin may modulate its own action on glucose metabolism in the tissues by changing ADA activity and hence local concentration adenosine (30). However, contradictory to these results, our data suggest that adenosine metabolism altered in DM. although mechanisms involved in this phenomenon are unclear at the present time.

ADA activity was increased in the lymph nodes and splenocytes of diabetes-prone BB rats (34) and increased in white adipocytes (16), duodenum (26), heart, and other tissue (30) of streptozotocin diabetic rats. Morever, insulin administration decreased the elevated ADA activity in these tissues (30). In this context, elevated activity of ADA in our patients may an alarming factor for insulin treatment.

We report in this study that ADA activity is elevated in the serum of type 2 diabetic patients and confirm a previous report (15). Morever, serum ADA activity was found to be higher in poorly controlled diabetics (HbAlc (7) than in well controlled diabetics (HbAlc<7). Also, ADA activity correlated with glycated hemoglobin level in diabetics, in our study.

ADA, by the localization on the external surface of the cell membrane, can regulate adenosine concentration in the extracellular space and modify adenosine action on its membrane receptors (26). At present, four adenosine receptors have been identified (A1, A2a, A2b, and A3). However, their relationship with cellular functions has not been clarified, and it is probably complex (3).

Adenosine is postulated to act as an endogenous (feedback) inhibitor of hormone activated lipolysis. Its potent antilipolytic and cyclic AMP (cAMP)-lowering effects are well known and the processes mediating these events have been defined (19). Koopmans et al (20) showed that adenosine inhibited adenylate cyclase through A1 adenosine receptors via the inhibitory G-protein (Gi) resulting in the inhibition of lipolysis. Removal of endogenous adenosine 
by ADA resulted in an immediate rise in lipolytic activity. Consequently, elevated ADA levels in diabetic patients may augment hyperlipidemia by increasing lipolysis (15). Also, agonists for the A1 adenosine receptor decrease cAMP in adipocytes, decreasing lipolysis and inhibiting glycerol release from adipose tissue (3). In our study, TG levels were higher than those of $\mathrm{C}$. However, there was no significant correlation in our patients between the ADA and lipid levels.

ADA catalyzes the irreversible deamination of adenosine to inosine and 2'-deoxyadenosine to 2'-deoxyinosine. Inosine and 2'-deoxyinosine are converted to hypoxanthine, xanthine and finally to uric acid. Therefore, increased ADA activity may result in overproduction of uric acid (15). This explains the higher uric acid levels in DM patients. Also, there was signinificant correlation between the ADA levels and uric acid in diabetics.

As a conclusion, the results of the present study indicate a relation between the ADA activity and type 2 DM. Elevated ADA activity, and increased triglyseride and uric acid levels in our patients may associate with the insulin resistance. On the other hand, increased activity of ADA in type $2 \mathrm{DM}$ might be a marker for insulin therapy indication. Further investigations are necessary for the clarification of pathogenic role of ADA in insulin resistance and DM.

\section{References}

1. Angielski S, Jakubowski Z, Pawelczyk T, Piec G, Redlak M. Renal handling and metabolism of adenosine in diabetic rats. Contrib Nephrol 1989;73:52-8.

2. Bartrons R, Van Schaftingen E, Hers H-G. The ability of adenosine to decrease the concentrations of fructose 2,6-bisphosphate in isolated hepatocytes. Biochem J 1984:218:157-63.

3. Bottini E, Gerlini G, Lucarini N, Amante A, and Gloria-Bottini F. Evidence of selective interaction between adenosine deaminase and acid phosphatase polymorphisms in fetuses carried by diabetic woman. Hum Genet 1991;87:199-200.

4. Budohoski L, Challiss RA, McManus B, Newsholme EA. Effects of analogues of adenosine and methyl xanthines on insulin sensitivity in soleus muscle of the rat FEBS Lett 1984;167:1-4.

5. Budohoski L, Challiss RA, Lozeman FJ, McManus B, Newsholme EA. Increased insulin sensitivity in soleus muscle from cold-exposed rats: reversal by an adenosine-receptor agonist. FEBS Lett 1984;175:402-6.

6. Challiss RA, Richards RA, Budohoski L. Characterization of the adenosine receptor modulating insulin action in rat skeletal muscle. Eur J Pharmacol 1992; 226(2):121-8.

7. Daly JW. Adenosine receptors. In Advances in Cyclic Nucleotide and Protein Phosphorylation Research. Vol 19. Cooper DMF, Seamon KB, Eds. New York; Raven, 1995:29-46.

8. Dods RF. DM. In Clinical Chemistry. Kaplan LA, Pesce AJ eds. Philadelphia; The CV Mosby Company, 1989:436-53.

9. Epsinal J, Challiss RA, Newsholme EA. Effect of analogues of adenosine and methyl xanthines on insulin sensitivity in soleus muscle of the rat. FEBS Lett 1983;167:1-4.

10. Ezzat WR, Lautt WW. Hepatic arterial pressure-flow autoregulation is adenosine mediated. Am J Physiol 1987;252:H836-45.

11. Felig P, Cherif A, Minagawa A, Wahren J. Hypoglycemia during prolonged exercise in normal men. N Engl J Med 1982;306:895-900.

12. Gilboe DP, Nuttall FQ. The synergistic action of caffeine or adenosine on glucose stimulation of liver glycogen synthase phosphatase activity. FEBS Lett 1984; 170:365-9.
13. Giusti G. Adenosine Deaminase. In; Bergmeyer HU, ed. Methods of Enzymatic Analysis. Newyork: Academic Press, 1974;2:1092-99.

14. Granner, DK. Hormones of the pancreas and GI tract. In Harper's Biochemistry. In; Murray RK, Mayes PA, Granner DK, Rodwell VW eds. Beiurut; Librairre du Luban, 1991:530-45.

15. Hoshino T, Yamada K, Masuoka K, et all. Elevated adenosine deaminase activity in the serum of patients with DM. Diabetes Res Clin Pract 1994;25:97-102.

16. Jamal Z, Saggerson E D. Enzymes involved in adenosine metabolism in rat white and brown adipocytes: effects of streptozotocin-diabetes, hypothyroidism, age and sex differences. Biochem J 1987;245: 881-886.

17. Jefferson LS, Exton JH, Butcher RW, Sutherland EW, Park CR. Role of adenosine 3',5'-monophosphate in the effects of insulin and anti-insulin serum on liver metabolism. J Biol Chem 1968;243:1031-38

18. Joost HG, Steinfelder HJ. Modulation of insulin sensitivity by adenosine effects on glucose transport, lipid synthesis, and insulin receptors of the adipocyte. Mol Pharmacol 1982;22:614-18.

19. Kather H. Pathways of purine metabolism in human adipocytes. J Biol Chem 1990; 265(1):96-102.

20. Koopmans SJ, Sips HCM, Bosman J, Radder JK, Krans HMJ. Antilipolytic action of insulin in adipocytes from starved and diabetic rats during adenosine-controlled incubations. Endocrinology 1989;125:3044-50.

21. Kruszynska YT, Home PD, Alberti KGMM. In vivo regulation of liver and skeletal muscle glycogen synthase activity by glucose and insulin. Diabetes 1986; 35:662-7.

22. Law WR, McLane MP, Raymond RM. Adenosine is required for myocardial insulin responsiveness in vivo. Diabetes 1988;37:842-5.

23. Law WR, Raymond RM. Adenosine potentiates insulin-stimulated myocardial glucose uptake in vivo. Am J Physiol 1988;254:970-5.

24. McLane MP, Black PR, Law WR, Raymond, RM. Adenosine reversal of in vivo hepatic responsiveness to insulin. Diabetes 1990;39:62-9.

25. Mortimore GE, King E Jr, Mondon CE,Glnsmann WH. Effects of insulin on net carbohydrate alterations in perfused rat liver. Am J Physiol 1967;212:179-83.

26. Namiot Z, Baranczuk E, Marcinkiewicz M, Wojcýk B. Adenosine deaminase activity in various parts of the gastrointestinal tract of streptozocin treated rats. Pharmazie 1993;48(H12):950.

27. Pilkis SJ, Chrisman TD, El-Maghrabi MR, et all. The action of insulin on hepatic fructose-2,6-bisphosphate metabolism. J Biol Chem 1983; 258:1495-503.

28. Raymond RM. Mechanism of skeletal muscle insulin resistance during endotoxinshock in the dog. Physiologist 1986;29:123.

29. Rodbell M. The role of hormone receptors and GTP-regulatory proteins in membrane transduction. Nature 1980;284:17-22.

30. Rutkiewicz $\mathbf{J}$ and Gorski J. On the role of insulin in regulation of adenosine deaminase activity in rat tissues Fed. Eur. Biochem Soc Lett 1990;271:79-80.

31. Schwabe U, Schonhofer PS, Ebert R. Facilitation by adenosine of the action of insulin on the accumulation of adenosine 3'5'-monophosphate., lipolysis, and glucose oxidation in isolated fat cells. Eur J Biochem 1974;46:537-45.

32. Taylor WM, Halperin ML. Stimulation of glucose transport in rat adipocytes by insulin, adenosine, nicotinic acid and hydrogen peroxide: role of adenosine 3':5'cyclic monophosphate. Biochem J 1979;178:381-9.

33. Wong EH, Smith JA, Jarett L. Effect of adenosine on insulin activation of rat adipocyte pyruvate dehydrogenase. FEBS Lett 1984;178:68-71.

34. Wu G, Marliss EB. Deficiency of purine nucleoside phosphorylase activity in thymocytes from the immunodeficient diabetic BB rats. Clin Exp Immunol 1991;86: $260-5$.

Submitted March 2003.

Accepted October 2003.

Sadrettin Pence, M.D., Ph.D., MBA,

Gaziantep University, Medical Faculty, Department of Physiology, 27310 Gaziantep, Turkey.

e-mail: sadrettinpence@yahoo.com 